\title{
mlo-Based Resistance: An Apparently Universal "Weapon" to Defeat Powdery Mildew Disease
}

\author{
Stefan Kusch and Ralph Panstruga \\ Unit of Plant Molecular Cell Biology, Institute for Biology I, RWTH Aachen University, Worringerweg 1, 52056 Aachen, Germany
}

Accepted 13 January 2017.

Loss-of-function mutations of one or more of the appropriate Mildew resistance locus o (Mlo) genes are an apparently reliable "weapon" to protect plants from infection by powdery mildew fungi, as they confer durable broad-spectrum resistance. Originally detected as a natural mutation in an Ethiopian barley landrace, this so-called mlo-based resistance has been successfully employed in European barley agriculture for nearly four decades. More recently, $m l o$-mediated resistance was discovered to be inducible in virtually every plant species of economic or scientific relevance. By now, mlo resistance has been found (as natural mutants) or generated (by induced mutagenesis, gene silencing, and targeted or nontargeted gene knock-out) in a broad range of monocotyledonous and dicotyledonous plant species. Here, we review features of mlo resistance in barley, discuss approaches to identify the appropriate Mlo gene targets to induce mlo-based resistance, and consider the issue of pleiotropic effects often associated with mlo-mediated immunity, which can harm plant yield and quality. We portray mlo-based resistance as an apparently universal and effective weapon to defeat powdery mildew disease in a multitude of plant species.

In temperate climates, the common and widespread powdery mildew disease constitutes a constant and ubiquitous threat to agriculture and horticulture (Glawe 2008). Worldwide, around 10,000 plant species are host to more than 650 species of powdery mildew fungi (Takamatsu 2004, 2008). Among these are cereals and crops such as barley (Hordeum vulgare), cucumber (Cucumis sativus), melon (Cucumis melo), pea (Pisum sativum), tomato (Solanum lycopersicum), and wheat (Triticum aestivum); fruits like apple (Malus domestica), grapevine (Vitis vinifera), peach (Prunus persica), and strawberry (Fragaria $\times$ ananassa; $F$. vesca); the spice plant pepper (Capsicum annuum); ornamental plants such as petunia (Petunia hybrida) and rose (Rosa hybrida); and other economically relevant plants, for example, tobacco (Nicotiana tabacum). Powdery mildew outbreaks often result in severe harvest losses, for instance by reduction of grain yield and quality in barley and wheat (Dean et al. 2012). Quantitative and race-specific resistances usually provide either incomplete or short-lived protection against powdery mildew disease (Jørgensen and Wolfe 1994).

In the 1930s and 1940s, a game-changing type of powdery mildew resistance was discovered. Loss-of-function of the gene

Corresponding author: R. Panstruga: Telephone: +49 241 8026655; E-mail: panstruga@bio1.rwth-aachen.de

() 2017 The American Phytopathological Society
Mildew resistance locus o (Mlo) in barley was found to confer recessively inherited broad-spectrum resistance against the ascomycete phytopathogen (Jørgensen 1992; Lyngkjær and Carver $2000)$. In contrast to prototypical resistance $(R)$ gene-mediated race-specific resistance, which is typically inherited dominantly or semidominantly, mlo-based resistance is non-race specific and, thus, effective against the vast majority of powdery mildew isolates (Brown 2015; Lyngkjær and Carver 2000). Out of the more than 40 barley mlo mutant alleles known to date (Reinstädler et al. 2010), the natural mlo-11 (Piffanelli et al. 2004) and the induced mlo-9 (Schwarzbach 1967) allele are the two mlo mutations predominantly deployed in agriculture since the late 1970s and early 1980s. Now, more than half of the spring barley commercially grown in central Europe is largely immune to powdery mildew, due to the introgression of mlo resistance into a broad panel of barley varieties (Jørgensen 1992; McGrann et al. 2014). Although mlo has been recently introgressed into a few winter barley lineages, this resistance is currently not yet employed in commercially grown winter barley (Czembor et al. 2016).

The barley Mlo gene was cloned about 20 years ago and was, subsequently, found to code for a member of a family of integral membrane proteins (Büschges et al. 1997; Devoto et al. 2003). As experimentally shown, barley Mlo is a plasma membranelocalized seven-transmembrane domain protein with an extracellular amino terminus and an intracellular carboxy-tail (Devoto et al. 1999). However, little is known about the molecular function of the protein. The carboxy-terminal tail, which is predicted to be intrinsically disordered (Kusch et al. 2016), includes a domain that binds calmodulin and is required for full susceptibility to powdery mildew infection in barley (Kim et al. 2002). Moreover, the protein possesses four conserved cysteines in two of the extracellular domains, likely important for structural integrity (Elliott et al. 2005), and a number of conserved short peptide motifs scattered in the intra- and extracellular domains (Appiano et al. 2015a; Kusch et al. 2016). However, at present the biochemical activity of the protein remains mysterious (AcevedoGarcia et al. 2014). Given that Mlo is coexpressed with genes involved in plant defense, it seems plausible that Mlo exerts a function in plant immunity (Humphry et al. 2010).

Characteristics of mlo resistance in barley.

The obligate biotrophic barley powdery mildew pathogen Blumeria graminis f. sp. hordei proliferates on the host upon penetration of the cell wall and "intracellular" establishment of the haustorium, which is the primary site of contact between the fungus and the plant cell (O'Connell and Panstruga 2006). Once the interaction is established, secondary hyphae emerge that spread epiphytically on the plant surface (Fig. 1A) and later 
give rise to conidiophores that bear new conidiospores (Bélanger et al. 2002). Barley mlo-based resistance is characterized by an effective arrest of fungal pathogenesis at very early stages of infection. Usually, B. graminis f. sp. hordei spores attempt to penetrate epidermal host cells but fail, as formation of haustoria and secondary hyphae is not observed on mlo genotypes (Fig. 1B). Consequently, sporulation does not occur and the fungus cannot complete its asexual life cycle (Fig. 2). Subsidiary cells of stomatal complexes are the exception, because rare powdery mildew colonies and even sporulation can be found after successful colonization of this cell type. The extent of this effect varies between mlo mutants dependent on the genetic background but is, seemingly, not dependent on the type of mlo allele (Jørgensen and Mortensen 1977).

Barley mlo-based prepenetration resistance is characterized by several distinctive features. Local cell-wall appositions (CWAs) that contain the $\beta$-glucan cell-wall polymer callose are found at attempted penetration sites of $B$. graminis $\mathrm{f}$. sp. hordei, which is reminiscent of the response to nonhost pathogens (Skou 1982; Skou et al. 1984). The number and diameter of these CWAs, or papillae, is increased in mlo mutants, compared with wild-type barley (Mlo genotype), upon interaction with $B$. graminis $\mathrm{f}$. sp. hordei (Stolzenburg et al. 1984). In addition, other defenseassociated compounds overaccumulate at $B$. graminis f. sp. hordei infection sites in barley mlo genotypes, including the phenol conjugate $p$-coumaroyl-hydroxyagmatine (von Röpenack et al. 1998) and reactive oxygen species such as hydrogen peroxide (Hückelhoven et al. 2000; Piffanelli et al. 2002). These events coincide with a faster and more pronounced accumulation of defense-related transcripts in mlo null mutant plants (Zierold et al. 2005). Mesophyll cells were further described to undergo localized cell death below sites of attempted B. graminis f. sp. hordei penetration, which can result in macroscopically visible necrotic leaf spots (Piffanelli et al. 2002).

\section{Requirements for mlo resistance in barley.}

Deciphering the molecular basis of mlo-based resistance has been subject of several studies. Chemical mutagenesis has been employed to identify suppressor mutants of mlo-based resistance, thereby uncovering two genetic loci required for full resistance, Required for mlo-specified resistance1 (Ror1) and Ror2 (Freialdenhoven et al. 1996). Both rorl and ror 2 mutations partially suppress penetration resistance to powdery mildew in barley mlo null mutant plants and reinstate host cell entry rates of up to $20 \%$ (Freialdenhoven et al. 1996). The Ror 2 protein encodes a t-SNARE (soluble $\mathrm{N}$-ethylmaleimide-sensitive factor attachment protein receptor) protein that is likely involved in pathogen-induced secretion of antimicrobial compounds at infection sites. Ror2 is considered to be the ortholog of Arabidopsis PENETRATION1 (PEN1), which contributes to nonhost resistance against powdery mildews (Collins et al. 2003). The Rorl gene has not been cloned yet, but its genomic location has been narrowed down to a 0.18 -cM interval in the peri-centromeric region of the long arm of chromosome 1H (Acevedo-Garcia et al. 2013). Ror1 and Ror2 seem to partake in two separate pathways that add to mlo-based resistance (Collins et al. 2003). The two proteins modulate mlo-dependent hyperaccumulation of hydrogen peroxide upon B. graminis f. sp. hordei challenge (Hückelhoven et al. 2000; Piffanelli et al. 2002) and also contribute to basal resistance against the rice blast pathogen, Magnaporthe grisea (Jarosch et al. 2005).

In addition to the genetic approach, pharmacological assays were devised to uncover requirements for $m l o$-based resistance in former studies. The glucose analog 2-deoxy-D-glucose (DDG) as well as mannose act as partial suppressors of mlo-based resistance to B. graminis f. sp. hordei, resulting in up to $15 \%$ host cell entry in the case of mannose and more than $50 \%$ penetration by $B$. graminis f. sp. hordei in the case of DDG. Furthermore, autofluorescence and size of papillae are affected by these treatments, suggesting that synthesis and localized deposition of callose is necessary for full resistance to powdery mildew in barley mlo plants (Bayles et al. 1990; Lyngkjær et al. 1997). Treatment of mannose or DDG in combination with $\alpha$-aminooxy$\beta$-phenylpropionic acid (AOPP) enhances this effect and further increases $B$. graminis $\mathrm{f}$. sp. hordei penetration rates, while AOPP alone is insufficient to affect mlo-based resistance. AOPP is an inhibitor of phenylalanine ammonia lyase, which catalyzes the first dedicated reaction in the synthesis of phenolics in plants (Lyngkjær et al. 1997). In addition, actin cytoskeleton function was discovered to be involved in mlo-based resistance. The actin cytoskeleton undergoes extensive reorganization upon powdery mildew attack, reorienting toward and accumulating at attempted host cell-entry sites. This reorganization occurs faster in mlo mutant cells, compared with Mlo-expressing cells, in response to B. graminis f. sp. hordei (Opalski et al. 2005). Treatment of barley leaves with the actin polymerization inhibitor cytochalasin E severely affects resistance to $B$. graminis f. sp. hordei in barley mlo plants, as does overexpression of actin depolymerizing factors (ADFs) (Miklis et al. 2007). ADFs increase the turnover of filamentous actin by depolymerization of globular monomeric actin from the polymer, thus negatively regulating actin polymerization (Carlier et al. 1997). Microtubule inhibitors (propyzamide, oryzalin), however, do not alter resistance to B. graminis f. sp. hordei in mlo mutant plants (Miklis et al. 2007).

Barley Mlo function is mechanistically linked to $\mathrm{Ca}^{2+}$ homeostasis. The ubiquitous $\mathrm{Ca}^{2+}$ sensor calmodulin binds to barley Mlo and this interplay is required for full susceptibility to B. graminis f. sp. hordei (Kim et al. 2002). Binding of calmodulin to Mlo increases during the B. graminis f. sp. hordei entry phase in planta (Bhat et al. 2005), while treatment with the $\mathrm{Ca}^{2+}$ chelator EGTA attenuates this interaction in vitro (Kim et al. 2002). Moreover, exogenous application of $\mathrm{Ca}^{2+}$ partially suppresses mlo resistance in barley coleoptiles (Bayles and Aist

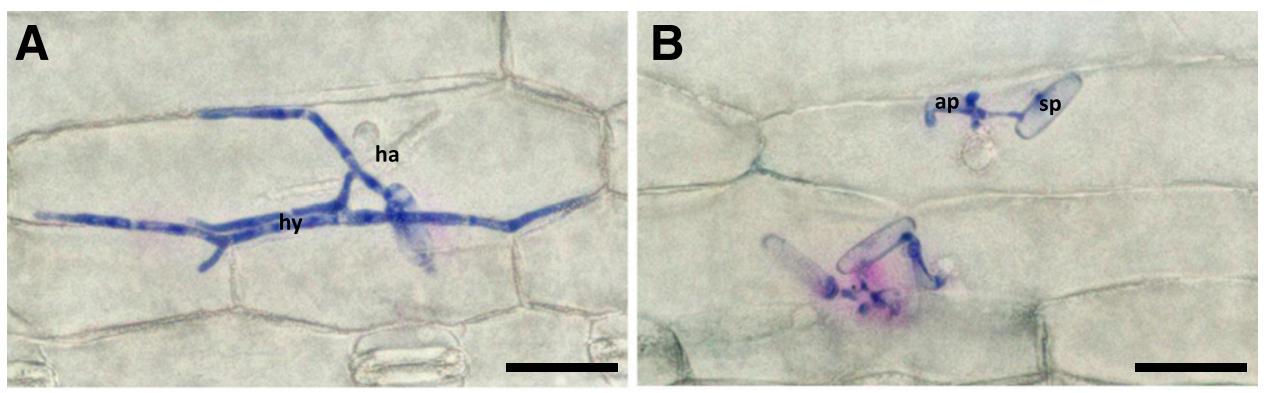

Fig. 1. mlo-based resistance prevents host cell penetration. Barley leaves were inoculated with Blumeria graminis f. sp. hordei (isolate K1) and photographs were taken at $48 \mathrm{~h}$ postinoculation. Fungal structures were stained with Coomassie brilliant blue. A, The plant lines were the susceptible cultivar Ingrid and B, mlo-3 in Ingrid background. $\mathrm{sp}=$ spore, $\mathrm{ap}=$ appressorium, ha $=$ haustorium, and hy $=$ hyphae. Scale bar $=30 \mu \mathrm{m}$. 
1987) and overexpression of the $\mathrm{Ca}^{2+}$-dependent protein kinase $H v \mathrm{CDPK} 3$ or the junction domain of $H v \mathrm{CDPK} 4$ in barley mlo cells partially increases the $B$. graminis f. sp. horde $i$ entry rate (Freymark et al. 2007). Taken together, cellular $\mathrm{Ca}^{2+}$ levels seem to modulate both Mlo function and mlo-based resistance.

Programmed cell death is an important factor of plant defense. BAX INHIBITOR 1 (BI-1) is a negative regulator of cytochrome c release-related stress-induced cell death in mammalian and plant cells. Barley BI-I expression is responsive to B. graminis $\mathrm{f}$. sp. hordei infection, and local overexpression of $B I-1$ in barley mlo cells reconstitutes susceptibility to $B$. graminis $\mathrm{f}$. sp. horde almost to wild-type levels, suggesting that regulation of cell death is another crucial aspect of mlo-based resistance (Hückelhoven et al. 2003). Further, BI-1 silencing increases resistance to powdery mildew in otherwise susceptible barley Mlo plants (Eichmann et al. 2010) and, at least in Arabidopsis, BI-1 was found to interact with calmodulin and requires intact $\mathrm{Ca}^{2+}$. dependent ATPases for cell death-inhibiting activity (Ihara-Ohori et al. 2007). Thus, BI-1 is a common element of cell death regulation and a modulator of penetration resistance.

Taken together, the combination of genetic and pharmacological assays suggests that multiple molecular processes and pathways collectively contribute to mlo-based resistance in barley. These include exocytosis mediated by the syntaxin Ror2, actin cytoskeleton function, callose biosynthesis and deposition, $\mathrm{Ca}^{2+}$-related pathways, as well as regulation of cell death.

Apple Arabidopsis Barley Cucumber Grapevine Melon
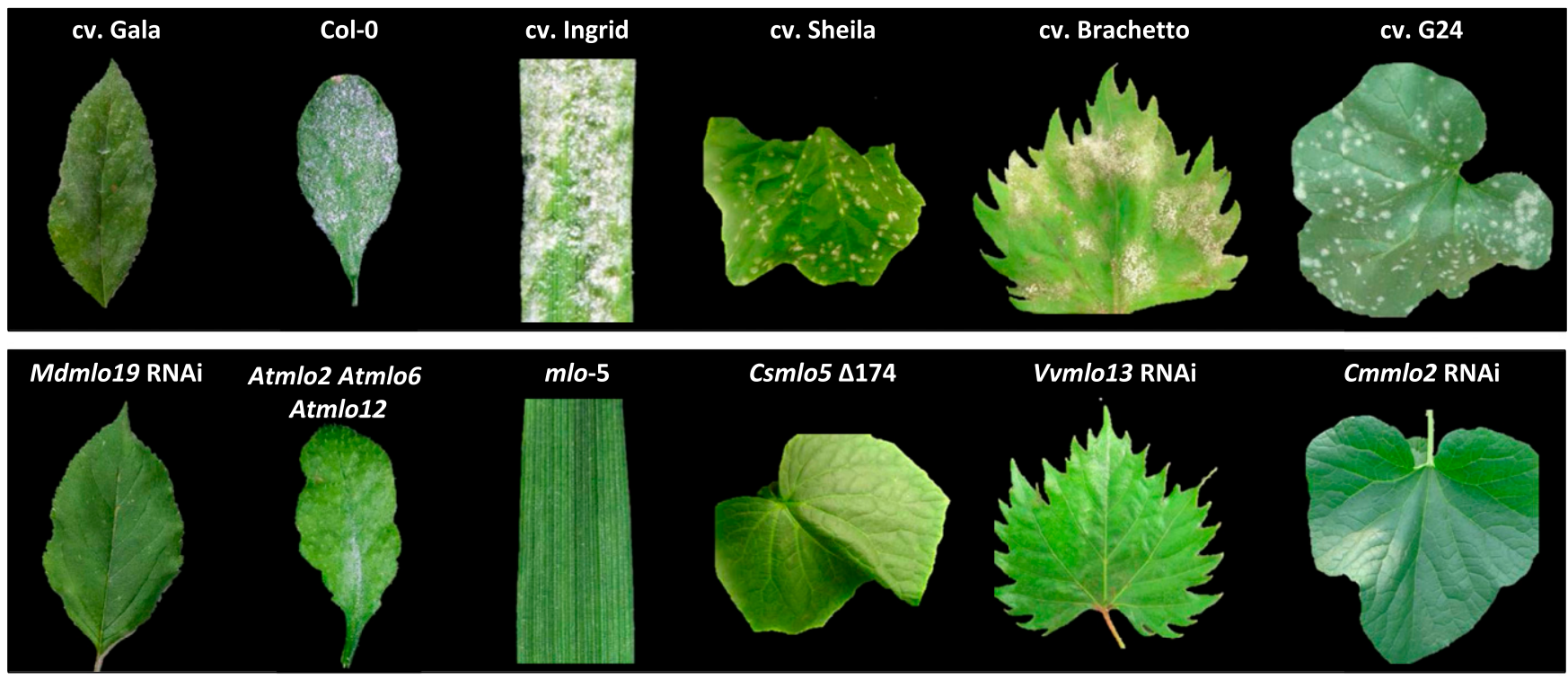

Pea Pepper Rose Tobacco Tomato Wheat

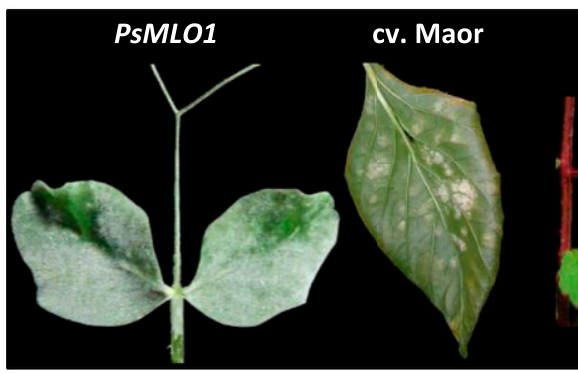

cv. Baiyu 35S:NtMLO2 cv. Moneymaker cv. Cadenza

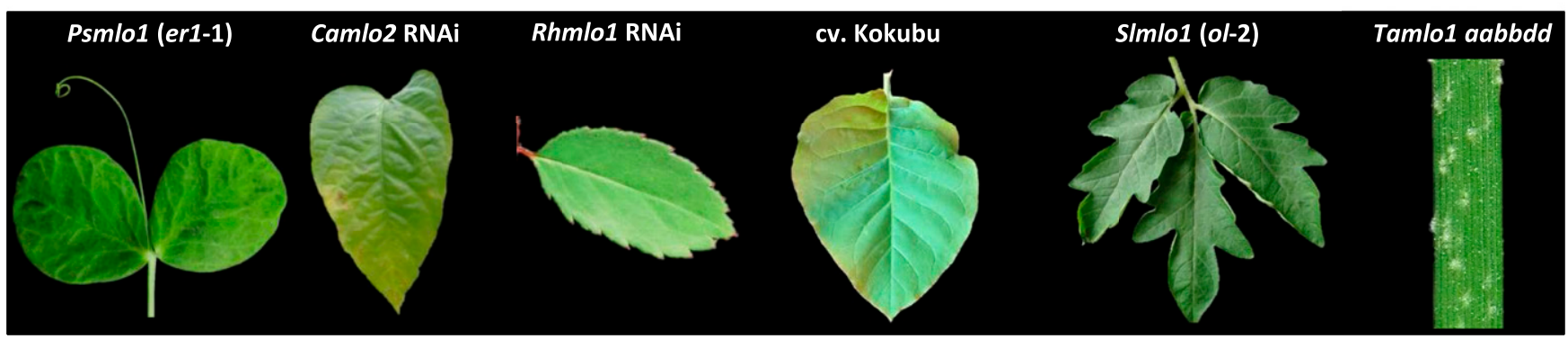

Fig. 2. Examples for mlo resistance in various plant species. The plant species were inoculated with the respective adapted powdery mildew species. Upper panel, susceptible wild-type or Mlo overexpression. Lower panel, powdery mildew-resistant line based on mlo loss-of-function. Species and the respective Mlo/mlo variant are indicated above each picture. Photographs were contributed by Y. Bai and S. Pessina (apple, grapevine), J. Berg (cucumber), Z. Zheng (pepper), M. Appiano (tomato), H. Cheng (melon), Z. Qiu and M. Bao (rose), K. Gruner (wheat), C. Consonni (Arabidopsis), and M. Arai (tobacco). 


\section{Modulation of barley mlo-based resistance}

\section{by abiotic and biotic factors.}

While mlo-based resistance is typically very stable in the field, several abiotic factors have been found to modulate this type of plant defense. A number of studies identified drought stress followed by sudden relief of this state (by watering) as a modulator of resistance, since several mlo-resistant barley cultivars experiencing this condition displayed moderate susceptibility to powdery mildew (Baker et al. 1998, 2000; Newton and Young 1996). Further, heat treatment $\left(36^{\circ} \mathrm{C}\right.$ for 30 to $\left.120 \mathrm{~min}\right)$ was discovered to partially break immunity of barley mlo leaf segments to powdery mildew. However, the weak, heat-induced susceptibility of mlo plants is temporary and resistance recovers to levels of unstressed leaves after $13 \mathrm{~h}$ (Schwarzbach 2001).

Some reports describe the occurrence of barley powdery mildew isolates that partially overcome mlo-based resistance. The natural Japanese isolate Race1 exhibits limited virulence on barley mlo null mutant plants, with colony numbers reaching up to $13 \%$ of a susceptible wild-type cultivar (Lyngkjær et al. 1995). In addition, field isolates with temporarily increased mlo virulence have been collected in the United Kingdom and Czech Republic, resulting in colony numbers of up to $16 \%$ of a susceptible Mlo genotype. However, this partially enhanced virulence was lost in subsequent generations (Schwarzbach et al. 2002). In contrast to these naturally occurring cases of partial mlo virulence, the $B$. graminis f. sp. horde $i$ isolate HL-3/HL-5 was selected toward enhanced virulence on mlo plants from the Czech isolate GE3 (Schwarzbach 1967, 1979). HL-3/HL-5 displayed a penetration rate of up to $18 \%$ on mlo null mutant plants but did not present increased aggressiveness on the respective susceptible (Mlo genotype) parental cultivar (Lyngkjær and Østergård 1998). Noticeably, mlo-virulent B. graminis f. sp. hordei strains do not appear to be prevalent or dominant in nature or agricultural settings, even though partially overcoming mlo-based resistance is, in principle, possible, as evidenced by the above-mentioned instances. Perhaps the combination of mlo-based resistance, isolate-specific resistance genes, and fungicides proves too high a barrier for B. graminis f. sp. hordei to adapt to. Alternatively, partially mlo-virulent $B$. graminis f. sp. hordei isolates may suffer from selective disadvantages in other respects.

\section{Pleiotropic phenotypes of barley mlo mutants.}

mlo-based resistance is unique, as it confers durable broadspectrum resistance specifically to powdery mildews but,

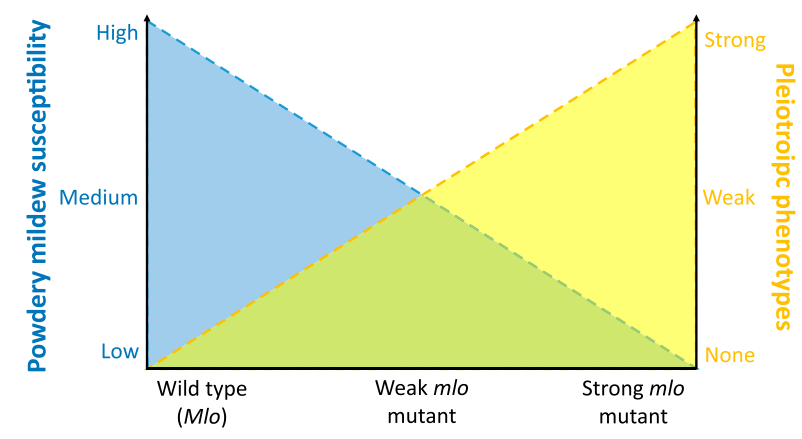

Fig. 3. Scheme illustrating the proposed Mlo-dependent anticorrelation of powdery mildew susceptibility and the extent of pleiotropic phenotypes. The relative level of susceptibility to powdery mildew is shown on the left $y$ axis, the relative level of pleiotropic phenotypes is given on the right $y$ axis. The hypothesized anticorrelation between these traits is depicted as being dependent on the plant genotype (Mlo/mlo), which is indicated on the $x$ axis Please note that, in this scheme, the correlations are shown to be linear, which is not necessarily the case (as symbolized by the dashed lines). This simplified scheme also does not take into account the developmental stage of the plant, which is an additional determinant of the extent of the pleiotropic phenotypes. seemingly, not to most other pathogens. The only exception reported so far is the hemibiotrophic oomycete Phytophthora palmivora, to which barley mlo plants are more resistant in younger leaf sections but not in older leaf areas or roots (Le Fevre et al. 2016). However, defense against some nonbiotrophic pathogens is affected in barley mlo plants. Barley mlo mutants were reported to be more susceptible to the hemibiotrophic rice blast fungus M. grisea, which is associated with increased leaf chlorosis upon infection and is independent from the Ror genes (Jarosch et al. 1999). The mutant was also found to be more sensitive to Bipolaris sorokiniana toxin-containing culture filtrates (Kumar et al. 2001) and to allow increased proliferation of the necrotrophic fungus Fusarium graminearum in barley spikes (Jansen et al. 2005). In addition, barley mlo plants show increased susceptibility to Ramularia leaf spot caused by Ramularia collo-cygni in a Rorl- and Ror2- as well as growth condition-dependent manner (McGrann et al. 2014; Pinnschmidt and Sindberg 2009). In contrast to these reports, a recent study determined that there seems to be no difference in colonization by Fusarium spp. and $R$. collo-cygni between mlo and wild-type (Mlo) barley plants under field conditions (Hofer et al. 2015). Collectively, these data suggest a trade-off between powdery mildew resistance and susceptibility to nonbiotrophic pathogens. Nevertheless, this trade-off might depend on the particular field or laboratory conditions.

Barley mlo mutants exhibit additional pleiotropic phenotypes that can impact harvest yields. A microscopically visible feature of mlo mutants is the spontaneous formation of CWAs, detectable as discrete callose-containing deposits in aging leaves in the absence of any pathogen or other obvious stress condition (Wolter et al. 1993). This situation is reminiscent of a deregulated defense program (lesion-mimic mutant [Walbot et al. 1983]). Likely as a further consequence of endogenously deregulated physiology, mlo mutants display early leaf senescence, which is characterized by spontaneous mesophyll cell death and premature chlorophyll decay, resulting in macroscopically visible leaf chlorosis and necrosis (Peterhänsel et al. 1997; Piffanelli et al. 2002; Wolter et al. 1993). This effect has also been reported in field trials in Scotland and Ireland. In the latter studies, barley mlo mutants showed consistently increased occurrence of abiotic leaf spots, emphasizing the potential problem of these pleiotropic effects for barley cultivation (Makepeace et al. 2007).

Interestingly, the recently described mlo-11 (cnv2) allele present in an Ethiopian landrace (Eth295), which exhibits partially relieved powdery mildew resistance, seemingly does not suffer from the early senescence phenotype (Ge et al. 2016). Similar observations have been made with induced barley mlo mutants (mlo-12 and mlo-28) that show a weak resistance phenotype (Hentrich 1979; Piffanelli et al. 2002). Notably, mlo-based resistance is effective at all developmental stages, while pleiotropic effects seem to be only apparent in mature or older (i.e., flowering or senescing) plants. Based on these data, an anticorrelation seems to exist between the level of powdery mildew susceptibility and the extent of premature leaf senescence in mlo plants (Fig. 3).

\section{Discovery of mlo resistance in other plant systems.}

Resistance conferred by loss-of-function mlo mutants was long believed to represent a unique feature of monocotyledonous barley. Approximately a decade ago, however, it was found that mlo-based resistance is also effective in the dicotyledonous model plant Arabidopsis thaliana (Table 1) (Consonni et al. 2006). Since then, $m l o$-based resistance has been described in many additional plant species (Fig. 2; Table 1; Box 1). These instances comprise naturally occurring resistant accessions of tomato and pea (Bai et al. 2008; Humphry et al. 2011) or induced mlo resistance in wheat (Acevedo-Garcia et al. 2017; Wang et al. 2014). Thus, mlo-based resistance emerges as a powerful and apparently 
universal genetic resource against powdery mildew disease in a wide range of angiosperms.

\section{Arabidopsis and barley reveal conserved features of $\boldsymbol{m l o}$-based resistance.}

Arabidopsis AtMLO2, AtMLO6, and AtMLO12 (please note that, in plant species other than barley, the nomenclature can either be $M l o$ or $M L O$; we use $M l o$ as the generic version throughout this article) were identified as co-orthologs of barley Mlo. Transgenic transfer-DNA (T-DNA) insertion lines and chemically induced mutants of MLO2 (syn. POWDERY MILDEW RESISTANCE2 [PMR2] [Vogel and Somerville 2000]) revealed that the three $M L O$ genes unequally add to the interaction with powdery mildew; AtMLO2 is the major and AtMLO6 and AtMLO12 are minor contributors to powdery mildew susceptibility. Accordingly, the Arabidopsis mlo2 mutant displays macroscopically visible resistance against powdery mildew but microscopically retains partial susceptibility concerning host cell penetration and the establishment of fungal microcolonies. The mlo2 mlo6 double mutant exhibits increased resistance and the mlo2 mlo6 mlo12 triple mutant is fully immune, resembling the phenotype of barley mlo plants (Consonni et al. 2006). Of the three single mutants, only mlo2 shows increased resistance to Golovinomyces cichoracearum and $G$. orontii, as infections are macroscopically symptom-less (Consonni et al. 2006). Similar to barley mlo plants, Atmlo2 lines display early senescence and chlorosis in aging rosette leaves as well as spontaneous callose deposition in unchallenged leaves.

Thanks to the availability of abundant genetic resources, extensive analyses have been performed to unravel the molecular basis of mlo resistance in Arabidopsis (Acevedo-Garcia et al. 2014; Kuhn et al. 2016). Similar to the ror 2 mutation in barley, the Arabidopsis pen1 mutation partially suppresses resistance of mlo2. In addition, PEN2 (a glycosyl hydrolase) and PEN3 (an $\mathrm{ABC}$ transporter), both involved in nonhost resistance against powdery mildews, are required for mlo2-based resistance (Consonni et al. 2006). The mlo2 mlo6 mlo12 mutant also hyperaccumulates salicylic acid (SA), but mutants affected in SA, jasmonic acid, or ethylene synthesis do not compromise mlo2-based resistance (Consonni et al. 2006). Further, mlo2 mutants show an age-dependent increase in steady-state levels of the phytoalexin camalexin and indolic glucosinolates. Accordingly, mutations in $C Y P 79 B 2 / C Y P 79 B 3$, encoding two redundant monooxygenases required for the synthesis of these tryptophanbased compounds, restore susceptibility to $G$. orontii in the mlo2 genotype (Consonni et al. 2010). In addition, POWDERY MILDEW RESISTANCE4 (PMR4)/GLUCAN SYNTHASELIKE5 has an effect on mlo2 mutants. mlo2 pmr4 mutants do not exhibit spontaneous callose deposition (as opposed to the mlo2 mutant) but resistance to powdery mildew is unaltered (Consonni et al. 2010). Taken together, these findings reveal that the essential characteristics of mlo-based resistance, such as prepenetration resistance and early leaf senescence, are conserved among monocots and dicots. Interestingly, however, mlo mutants in some plant species, such as apple, melon, pea, tobacco, and tomato, do not seem to suffer from undesired pleiotropic phenotypes (Table 1) (Bai et al. 2008; Cheng et al. 2015; Fujimura et al. 2016; Humphry et al. 2011; Pessina et al. 2016a). Whether these are species-specific or simply condition-dependent differences still needs to be explored.

\section{Sources of mlo mutants.}

Naturally occurring plant accessions exhibiting mlo-based resistance are an obvious source for mlo mutants and, in the case of barley and pea, are widely employed for breeding and agriculture. Ethiopian landraces of barley were the first known example of such natural mlo mutants. This mutant (designated mlo-11) carries a complex repeat array consisting of multiple partial copies of the Mlo gene directly upstream of the genuine Mlo gene copy, causing accumulation of aberrant transcripts and a massive reduction of the authentic Mlo transcript (Piffanelli et al. 2004). Interestingly, the landrace Eth295, a recently discovered derivative of the mlo-11 mutant, is an example of a natural variant showing partial mlo-based resistance but not its usually associated pleiotropic phenotypes (Ge et al. 2016). In addition to barley, natural mlo mutants of a different type (e.g., single nucleotide polymorphisms, small insertions or deletions [indels] and transposon insertions) have been found in cucumber (Berg et al. 2015), melon (Cheng et al. 2015), pea (Humphry et al. 2011; Pavan et al. 2011; Sun et al. 2016a and b),

Table 1. Functionally validated examples of mlo-based powdery mildew resistance (in chronological order)

\begin{tabular}{|c|c|c|c|c|}
\hline Plant species & Mlo gene & Type $^{\mathbf{a}}$ & Pleiotropic phenotypes ${ }^{b}$ & Reference \\
\hline Hordeum vulgare (barley) & Mlo & $\begin{array}{l}\text { Natural, chemical, } \\
\text { radiation }\end{array}$ & $\begin{array}{l}\text { CWAs, premature } \\
\text { senescence }\end{array}$ & $\begin{array}{l}\text { Jørgensen } 1992 \\
\text { Wolter et al. } 1993\end{array}$ \\
\hline Arabidopsis thaliana (thale cress) & $\begin{array}{l}\text { AtMLO2 } \\
\text { AtMLO6 } \\
\text { AtMLO12 }\end{array}$ & T-DNA, chemical & $\begin{array}{l}\text { CWAs, premature } \\
\text { senescence }\end{array}$ & Consonni et al. 2006 \\
\hline Solanum lycopersicum (tomato) & SlMLO1 & Natural & None & Bai et al. 2008 \\
\hline Pisum sativum (pea) & PsMLO1 & Natural, chemical & None & $\begin{array}{l}\text { Humphry et al. } 2011 \\
\text { Pavan et al. } 2011 \\
\text { Sun et al. } 2016 \mathrm{a} \\
\text { Sun et al. } 2016 \mathrm{~b}\end{array}$ \\
\hline Fragaria vesca (strawberry) & Unknown $^{\mathrm{c}}$ & RNAi & Unknown & Jiwan et al. 2013 \\
\hline Capsicum annuиm (pepper) & CaMLO2 & RNAi & Reduced plant size & Zheng et al. 2013 \\
\hline Triticum aestivum (bread wheat) & TaMlol & TALEN, TILLING & Premature senescence & $\begin{array}{l}\text { Wang et al. } 2014 \\
\text { Acevedo-Garcia et al. } 2017\end{array}$ \\
\hline Cucumis sativus (cucumber) & CsMLO5 & Natural & Unknown & $\begin{array}{l}\text { Berg et al. } 2015 \\
\text { Nie et al. } 2015\end{array}$ \\
\hline Rosa hybrida (rose) & $R h M L O 1$ & RNAi & Unknown & Qiu et al. 2015b \\
\hline Nicotiana tabacum (tobacco) & NtMLO1 & Natural & None & Fujimura et al. 2016 \\
\hline Cucumis melo (melon) & $\mathrm{CmMLO2}$ & Natural & None & Cheng et al. 2015 \\
\hline Vitis vinifera (grapevine) & $V v M L O 6, V v M L O 7$ & RNAi & Unknown & Pessina et al. 2016b \\
\hline Malus domestica (apple) & MdMLO19 & RNAi & None & Pessina et al. 2016a \\
\hline
\end{tabular}

a $\mathrm{T}$-DNA $=$ transfer-DNA, RNAi = RNA interference, TALEN = transcription activator-like effector nucleases, and TILLING = targeting induced lesions in genomes.

$\mathrm{b}$ CWA = cell-wall appositions. None indicates none observed in the tested growth regimes and unknown indicates the aspect was not mentioned in the respective publications.

${ }^{\mathrm{c}}$ Unknown = aspect not mentioned in the respective publications. 
tobacco (Fujimura et al. 2016), and tomato (Bai et al. 2008). These examples illustrate that naturally occurring landraces and accessions can be a rich source for mlo mutants.

Another widely explored source of mlo mutants is chemicalor radiation-based mutagenesis. The plant genotype of choice is either exposed to a chemical mutagen, e.g., ethyl methanesulfonate (EMS) or sodium azide $\left(\mathrm{NaN}_{3}\right)$, or a physical mutagen such as gamma radiation, and then, the respective offspring is selected for the desired powdery mildew resistance phenotype. Many of the known barley mutant alleles have been generated by radiation or $\mathrm{EMS} / \mathrm{NaN}_{3}$ mutagenesis, resulting in point mutations or small indels (Jørgensen 1992; Reinstädler et al. 2010). Some Arabidopsis mlo2 (pmr2) mutant lines have been generated by EMS mutagenesis as well (Consonni et al. 2006; Vogel and Somerville 2000). Combining induced mutagenesis with high-throughput genotyping for mutations in a given Mlo gene by a method called TILLING (targeting induced lesions in genomes) represents a fast, powerful, and nontransgenic procedure for the detection of mlo mutants even in complex genomes. For example, simultaneous mutation of the wheat homeologs of TaMlol (Al, B1,Dl) has been achieved by this method, producing several mutant combinations that display increased powdery mildew resistance (Acevedo-Garcia et al. 2017).
Another frequently used approach is gene silencing of candidate Mlo genes in the species of interest. This method takes advantage of the plant-endogenous RNA silencing machinery by providing small double-stranded RNA target sequences of the respective Mlo gene. In tomato, transient virus-induced gene silencing (VIGS) was one of the methods employed to show that SlMlol is the gene responsible for powdery mildew susceptibility (Bai et al. 2008). A weak contribution of SlMlo5 and SlMlo8 to powdery mildew susceptibility was suggested in a later study using RNA interference (RNAi) in a susceptible tomato cultivar (Zheng et al. 2016). A VIGS-based approach was also utilized in pepper to silence CaMLO1 and CaMLO2 in the context of the interaction with Leveillula taurica, thereby enhancing resistance to this endophytic powdery mildew pathogen (Zheng et al. 2013). VIGS and other RNAi approaches were further followed in wheat (Várallyay et al. 2012) and several members of the family Rosaceae, e.g., apple, grapevine, rose, and strawberry (Jiwan et al. 2013; Pessina et al. 2016b; Pessina et al. 2016a; Qiu et al. 2015b). Most of these transgenic approaches were, however, limited to the validation of candidate Mlo genes that contribute to susceptibility to powdery mildew.

Recent advances in precision genome editing now allow targeted mutagenesis of a specific locus in plants. The respective

\section{Box 1. Species with documented mlo-based powdery mildew resistance}

Monocots

Barley (Hordeum vulgare)

- Archetype of mlo-based resistance (Jørgensen 1992).

- More than 40 mutant alleles known (Reinstädler et al. 2010).

- Most extensively studied Mlo protein, with experimental work focusing on interaction partners (Kim et al. 2002), protein stability (Elliott et al. 2005), structure-function analysis (Elliott et al. 2002, 2005; Reinstädler et al. 2010), and in planta protein dynamics (Bhat et al. 2005).

Wheat (Triticum aestivum)

- Three near-identical orthologs of barley Mlo: TaMlo-A1, TaMlo-B1, and TaMlo-D1 (Elliott et al. 2002).

- Completely resistant TALEN/Cas9-derived triple mutants (Wang et al. 2014) and partially resistant TILLING-based mutants (Acevedo-Garcia et al. 2017).

\section{Dicots}

Apple (Malus domestica)

- Twenty-one $M L O$ genes, four of which sort into phylogenetic clade V (Pessina et al. 2014).

- Two of these, MdMLO11 and MdMLO19, and the clade VII member MdMLO18 transcriptionally induced upon challenge with Podosphaera leucotricha (Pessina et al. 2014).

- Knockdown of MdMLO19 but not of MdMLO11 reduces symptoms by $75 \%$ (Pessina et al. 2016a).

Arabidopsis (Arabidopsis thaliana)

- AtMLO2, AtMLO6, and AtMLO12 co-orthologs of barley Mlo (Consonni et al. 2006).

- First example of a species where mutations in multiple Mlo genes cooperatively contribute to full resistance (unequal genetic redundancy [Consonni et al. 2006]).

- Availability of ample genetic resources enables analysis of the molecular basis of mlo resistance (Consonni et al. 2006, 2010). Cucumber (Cucumis sativus)

- Three clade V MLO genes closely related to AtMLO2 (Schouten et al. 2014).

- One of these, CsMLO13, transcriptionally induced upon powdery mildew attack (Schouten et al. 2014).

- Transgenic expression of CsMLO5 in the tomato Slmlo1 mutant restores susceptibility to Oidium neolycopersici (Berg et al. 2015).

- Four natural Cucumis sativus mutant alleles of CsMLO5 confer resistance to Podosphaera xanthii (Berg et al. 2015 ; Nie et al. 2015).

Grapevine (Vitis vinifera)

- Four $M L O$ orthologs of AtMLO2, three of which are transcriptionally induced upon Erysiphe necator infection (Feechan et al. 2008; Winterhagen et al. 2008).

- Transgenic expression of $V v M L O 11$ and $V v M L O 13$ in the Arabidopsis mlo2 mlo6 mlo12 triple mutant confers partial susceptibility to Erysiphe cichoracearum (Feechan et al. 2013).

- Contradictory, RNAi-based knockdown of VvMLO6 and VvMLO7 but not VvMLO11 and VvMLO13 results in increased resistance to Erysiphe necator (Pessina et al. 2016b). 
methods enable specific binding of one or more nucleases to a genomic sequence of interest, which can induce single- or doublestrand breaks. Subsequent error-prone DNA repair on the basis of nonhomologous end-joining can then result in the formation of indel mutations at a specific genomic locus. Transcription activator-like effector nucleases (TALENs), originating from the plant-pathogenic bacterial genus Xanthomonas (Boch et al. 2009), have been used in wheat for simultaneous mutagenesis of the three TaMlo1 homeologs. The knock-out of TaMlo-A1, TaMlo-B1, and TaMlo-D1 by short indels induced full powdery mildew resistance (Wang et al. 2014). Additionally, in this study, a clustered regularly interspaced short palindromic repeat (CRISPR)-Cas9 construct was employed to target TaMlo-A1. CRISPR-Cas9 is an alternative genome editing tool that consists of CRISPR single guide RNA, including the approximately 20-bp target sequence, or protospacer, and the nuclease Cas9 from Streptococcus pyogenes. The sgRNA directs Cas9 to the DNA target sequence (Jinek et al. 2012).

In sum, these examples nicely illustrate that mlo mutants can be retrieved from many sources and via different experimental approaches, depending on the specific demands, including the selection of natural mutants, induced mutagenesis, knockdown by gene silencing, and state-of-the-art genome modification methods.

\section{Predicting the appropriate Mlo target.}

In order to target one or more of the correct Mlo genes for induction of powdery mildew resistance, suitable candidates have to be identified. Since Mlo genes are typically present as medium-sized families with 10 to 25 members per plant species (Kusch et al. 2016), the majority of these not involved in biotic stress functions, this task is not trivial. Generally, successful approaches include i) analysis of sequence similarity and phylogenetic relationship of candidate Mlo genes to described Mlo genes with a role in powdery mildew susceptibility, ii) evaluation of candidate Mlo transcript profiles upon powdery mildew infection, and iii) functional assessment based on bioassays.

The basic phylogenetic relationships within the Mlo protein family have been well-resolved. Mlo proteins involved in powdery mildew susceptibility belong to clade IV in monocots and clade V in dicots (Acevedo-Garcia et al. 2014; Kusch et al. 2016). Based on this knowledge, the identification of suitable Mlo genes by whole-genome surveys followed by phylogenetic classification has become common practice. These analyses also include searches for conserved peptide motifs, especially the C-terminally located tetra-peptide [DE]FSF seemingly always present in Mlo proteins involved in powdery mildew susceptibility (Panstruga 2005).

Often, several candidate Mlo genes are identified based on phylogeny and sequence analysis. The next step could be to analyze the expression pattern of the candidate Mlo genes by one or a combination of quantitative reverse transcriptionpolymerase chain reaction, microarray analysis, or whole genome shotgun RNA sequencing in the relevant tissues and upon powdery mildew attack. This approach is based on the previous

Box 1. (Continued from preceding page)

Melon (Cucumis melo)

- Sixteen melon MLO proteins, three of which classified as clade V (Iovieno et al. 2015).

- CmMLO2, CmMLO3 and CmMLO13 upregulated upon Podosphaera xanthii infection (Howlader et al. 2016).

- A natural mutant variant of CmMLO5 confers resistance to Podosphaera xanthii (Cheng et al. 2015).

Pea (Pisum sativum)

- Six natural Psmlol (erl) alleles and one induced mutant described that confer resistance to Erysiphe pisi (Humphry et al. 2011; Pavan et al. 2011; Sun et al. 2015, 2016a and b).

- Some of these extensively used in breeding without knowing the identity of the underlying gene (Rubiales and Fondevilla 2012).

Pepper (Capsicum annuum)

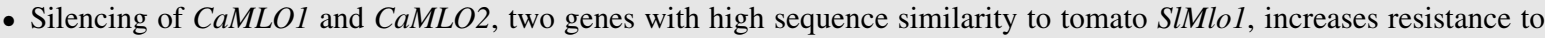
Leveillula taurica but also results in reduced plant size (Zheng et al. 2013).

- Silencing of CaMLO2 also enhances resistance to the bacterial pathogen Xanthomonas campestris pv. vesicatoria (Kim and Hwang 2012).

Rose (Rosa hybrida)

- Four MLO genes with close phylogenetic relationship to AtMLO2 and SlMlol (Kaufmann et al. 2012).

- Two of these, RhMLO1 and RhMLO2, transcriptionally induced upon infection with Podosphaera pannosa (Qiu et al. 2015a).

- Silencing of RhMLO1 results in enhanced resistance to P. pannosa (Qiu et al. 2015b).

Strawberry (Fragaria spp.)

- Three clade V MLOs identified (Miao et al. 2016; Pessina et al. 2014).

- Expression of a peach (Prunus persica) clade V MLO antisense fragment in Fragaria $\times$ ananassa garden strawberry results in increased resistance to Podosphaera macularis (Jiwan et al. 2013).

Tobacco (Nicotiana tabacum)

- Five clade V MLO genes identified (Appiano et al. 2015b).

- Overexpression of one of these, NtMLO1, in the tomato Slmlo1 mutant results in partial susceptibility to Oidium neolycopersici (Appiano et al. 2015b).

- Japanese tobacco cultivars, including Kokubu, exhibit resistance based on mutations affecting NtMLO1 and NtMLO2 (Fujimura et al. 2016).

- Transgenic tobacco cv. Kokubu expressing NtMLO1 or NtMLO2 display increased susceptibility (Fujimura et al. 2016). Tomato (Solanum lycopersicum)

- The natural tomato ol-2 mutant is defective in SlMlol and shows resistance to Oidium neolycopersici (Bai et al. 2008) and the endophytic powdery mildew pathogen Leveillula taurica (Zheng et al. 2013).

- A later study identified three additional clade V SlMlo genes, and silencing of these suggests a minor contribution of SlMlo5 and SlMlo8 to susceptibility (Zheng et al. 2016). 
notion that transcript levels of the Mlo genes that confer susceptibility to powdery mildew typically increase following pathogen challenge (Feechan et al. 2008; Howlader et al. 2016; Humphry et al. 2010; Pessina et al. 2014; Piffanelli et al. 2002; Qiu et al. 2015a; Schouten et al. 2014; Winterhagen et al. 2008; Zheng et al. 2013). Thus, responsiveness to biotic stress at the transcriptional level can be considered a further criterion to narrow down one or more appropriate Mlo target genes.

For functional validation, three main methodologies have been described in the literature: i) silencing of one or more Mlo candidate genes via VIGS or RNAi in the plant species of interest, ii) overexpression of one or more Mlo candidate genes in a mlo mutant variant of this plant, or iii) overexpression of one or more Mlo candidate genes in a heterologous plant system with well-defined mlo resistance, i.e., Arabidopsis mlo2 mlo6 mlo12, tomato Slmlo1, or barley mlo. In each case, the effect of Mlo silencing or overexpression is assessed by scoring the powdery mildew infection success micro- or macroscopically or both. The mentioned approaches have been efficiently used in case of many plant species, including wheat (Acevedo-Garcia et al. 2017; Elliott et al. 2002; Várallyay et al. 2012), grapevine (Feechan et al. 2008, 2013; Pessina et al. 2016b; Winterhagen et al. 2008), rose (Kaufmann et al. 2012; Qiu et al. 2015a and b), pepper (Zheng et al. 2013), and apple (Pessina et al. 2014, 2016a), demonstrating the feasibility of this integrated strategy to identify one or more appropriate $M l o$ gene targets.

\section{Concluding remarks.}

In this essay, we portray mlo-based resistance as a powerful and durable "weapon" against powdery mildew infection, not only in barley but in a wide variety of crop, fruit, and other plant species, including both dicots and monocots. To our knowledge, mlo resistance seems to be a universal phenomenon, as we do not know of any example where loss-of-function of one or more of the appropriate clade IV and clade V Mlo genes failed to confer powdery mildew resistance. Thus, presence of one or more respective Mlo proteins seems to be a general prerequisite for successful powdery mildew colonization. There are, however, plant species (e.g., rice and maize) that harbor seemingly adequate clade IV Mlo genes but are not host to powdery mildews. Hence, other factors such as additional plant or pathogen components or climatic conditions, or both, also appear to be crucial for powdery mildew pathogenesis. Mlo proteins are, therefore, necessary but not sufficient to mediate colonization of a given plant species by powdery mildew fungi.

In the meantime, mlo resistance is widely used in plant breeding in several plant species, including barley, pea, and tomato. The tools are now available to predict one or more adequate Mlo targets and to test their function by a variety of assays. Modern precision gene editing technologies emerge as the methods of choice to induce Mlo knock-outs in a targeted manner. However, there is a still ongoing debate whether such approaches are to be considered transgenic or not (Huang et al. 2016). For the time being, TILLING remains an attractive and undoubtedly nontransgenic alternative to select suitable mlo mutants (Acevedo-Garcia et al. 2017).

Yet, many aspects regarding the molecular basis of mlo resistance remain unanswered to date. Due to its requirement for successful plant colonization, MLO is often referred to as a susceptibility factor for powdery mildews (van Schie and Takken 2014). On the other hand, coexpression data suggest an authentic function for MLO proteins in plant immunity and, thus, rather a potential role as a negative regulator of plant defense (Humphry et al. 2010). The latter would be consistent with the fact that mlo mutant plants show resemblance to mild lesion-mimic mutants (Walbot et al. 1983). Recently, many lesion-mimic mutants have been shown to be suppressed by second-site mutations in genes coding for nucleotide binding site-leucine-rich repeat-type resistance proteins or pivotal defense signaling components, such as PAD4. It has been concluded that, in these instances, constitutive immunity and the lesion-mimic phenotype are the result of the inappropriate activation of resistance proteins due to the lack of the matching "guardee". In such a scenario, MLO would represent the guardee that is guarded by a yet-unknown resistance protein, which would be constitutively active in the absence of MLO. However, the fact that $m l o$-mediated immunity and resistance gene-based immunity have differential genetic requirements in barley (Freialdenhoven et al. 1994, 1996) argues against such a scenario. Furthermore, resistance conditioned by the Arabidopsis mlo2 mutant is not suppressed by mutations in $P A D 4$, which is a necessary signaling component acting downstream of resistance proteins with an $\mathrm{N}$-terminal toll interleukin 1 receptor domain (Consonni et al. 2006). Finally, resistance of mlo mutants is specific for powdery mildews, which is also inconsistent with such a setting. The exact role of MLO during fungal invasion thus remains unresolved for the time being.

Further key questions to be addressed by future research comprise the following:

Is mlo resistance indeed a universal phenomenon in angiosperm plants?

What are the defense pathways involved (what arrests fungal pathogenesis)?

Why is mlo resistance so durable?

Why do mlo mutants of some plant species show pleiotropic phenotypes, while mlo mutants of other plant species do (seemingly) not?

Can we uncouple resistance from pleiotropic phenotypes, e.g., by mutation of particular regulatory genes?

Why do some powdery mildew isolates have the capacity to overcome mlo-based resistance?

What is the biochemical activity of the Mlo protein?

Why is the presence of the Mlo protein required for successful powdery mildew pathogenesis?

Solving these issues is an important task for the coming years, as a deep understanding of the Mlo protein, the molecular mechanism of immunity, and the relationship between mlo-based resistance and potential pleiotropic phenotypes will help in designing the most efficient lines for defeating powdery mildew and for improving harvest yield and quality in the future.

\section{ACKNOWLEDGMENTS}

We thank everyone who provided photographs of various plant species infected with powdery mildew: Y. Bai and S. Pessina (apple, grapevine), J. Berg (cucumber), Z. Zheng (pepper), M. Appiano (tomato), H. Cheng (melon), Z. Qiu and M. Bao (rose), K. Gruner (wheat), C. Consonni (Arabidopsis), and M. Arai (tobacco). This work was supported by the German Research Foundation (Deutsche Forschungsgemeinschaft) (grant PA861/11-1 to R. Panstruga).

\section{LITERATURE CITED}

Acevedo-Garcia, J., Collins, N. C., Ahmadinejad, N., Ma, L., Houben, A., Bednarek, P., Benjdia, M., Freialdenhoven, A., Altmüller, J., Nürnberg, P., Reinhardt, R., Schulze-Lefert, P., and Panstruga, R. 2013. Fine mapping and chromosome walking towards the Rorl locus in barley (Hordeum vulgare L.). Theor. Appl. Genet. 126:2969-2982.

Acevedo-Garcia, J., Kusch, S., and Panstruga, R. 2014. Magical mystery tour: MLO proteins in plant immunity and beyond. New Phytol. 204: 273-281.

Acevedo-Garcia, J., Spencer, D., Thieron, H., Reinstädler, A., HammondKosack, K. E., Phillips, A. L., and Panstruga, R. 2017. mlo-based powdery mildew resistance in hexaploid bread wheat generated by a non-transgenic TILLING approach. Plant Biotechnol. J. 15: 367-378. 
Appiano, M., Catalano, D., Santillán Martínez, M., Lotti, C., Zheng, Z., Visser, R. G. F., Ricciardi, L., Bai, Y., and Pavan, S. 2015a. Monocot and dicot MLO powdery mildew susceptibility factors are functionally conserved in spite of the evolution of class-specific molecular features. BMC Plant Biol. 15:257.

Appiano, M., Pavan, S., Catalano, D., Zheng, Z., Bracuto, V., Lotti, C., Visser, R. G. F., Ricciardi, L., and Bai, Y. 2015b. Identification of candidate $M L O$ powdery mildew susceptibility genes in cultivated Solanaceae and functional characterization of tobacco NtMLO1. Transgenic Res. 24:847-858.

Bai, Y., Pavan, S., Zheng, Z., Zappel, N. F., Reinstädler, A., Lotti, C., de Giovanni, C., Ricciardi, L., Lindhout, P., Visser, R. G. F., Theres, K., and Panstruga, R. 2008. Naturally occurring broad-spectrum powdery mildew resistance in a Central American tomato accession is caused by loss of Mlo function. Mol. Plant-Microbe Interact 21:30-39.

Baker, S. J., Newton, A. C., Crabb, D., Guy, D. C., Jefferies, R. A., Mackerron, D. K. L., Thomas, W. T. B., and Gurr, S. J. 1998. Temporary partial breakdown of mlo-resistance in spring barley by sudden relief of soil water-stress under field conditions: The effects of genetic background and mlo allele. Plant Pathol. 47:401-410.

Baker, S. J., Newton, A. C., and Gurr, S. J. 2000. Cellular characteristics of temporary partial breakdown of mlo-resistance in barley to powdery mildew. Physiol. Mol. Plant Pathol. 56:1-11.

Bayles, C. J., and Aist, J. R. 1987. Apparent calcium mediation of resistance of an $m l$ - $o$ barley mutant to powdery mildew. Physiol. Mol. Plant Pathol. 30:337-345.

Bayles, C. J., Ghemawat, M. S., and Aist, J. R. 1990. Inhibition by 2-deoxyD-glucose of callose formation, papilla deposition, and resistance to powdery mildew in an ml-o barley mutant. Physiol. Mol. Plant Pathol. 36:63-72.

Bélanger, R. R., Bushnell, W. R., Dik, A. J., and Carver, T. L. W. 2002. The powdery mildews: A comprehensive treatise. APS Press, St. Paul, Minn.

Berg, J. A., Appiano, M., Santillán Martínez, M., Hermans, F. W. K., Vriezen, W. H., Visser, R. G. F., Bai, Y., and Schouten, H. J. 2015. A transposable element insertion in the susceptibility gene CsaMLO8 results in hypocotyl resistance to powdery mildew in cucumber. BMC Plant Biol. 15:243.

Bhat, R. A., Miklis, M., Schmelzer, E., Schulze-Lefert, P., and Panstruga, R. 2005. Recruitment and interaction dynamics of plant penetration resistance components in a plasma membrane microdomain. Proc. Natl. Acad. Sci. U.S.A. 102:3135-3140.

Boch, J., Scholze, H., Schornack, S., Landgraf, A., Hahn, S., Kay, S., Lahaye, T., Nickstadt, A., and Bonas, U. 2009. Breaking the code of DNA binding specificity of TAL-type III effectors. Science 326:1509-1512.

Brown, J. K. M. 2015. Durable resistance of crops to disease: A Darwinian perspective. Annu. Rev. Phytopathol. 53:513-539.

Büschges, R., Hollricher, K., Panstruga, R., Simons, G., Wolter, M. Frijters, A., van Daelen, R., van der Lee, T., Diergaarde, P., Groenendijk, J., Töpsch, S., Vos, P., Salamini, F., and Schulze-Lefert, P. 1997. The barley Mlo gene: A novel control element of plant pathogen resistance. Cell 88:695-705.

Carlier, M.-F., Laurent, V., Santolini, J., Melki, R., Didry, D., Xia, G.-X., Hong, Y., Chua, N.-H., and Pantaloni, D. 1997. Actin depolymerizing factor (ADF/cofilin) enhances the rate of filament turnover: Implication in actin-based motility. J. Cell Biol. 136:1307-1322.

Cheng, H., Kong, W., Lü, J., and Li, J. 2015. Analysis of powdery mildew resistance in wild melon $M L O$ mutants. Hortic Plant $\mathrm{J}$ 1:165-171.

Collins, N. C., Thordal-Christensen, H., Lipka, V., Bau, S., Kombrink, E., Qiu, J.-L., Hückelhoven, R., Stein, M., Freialdenhoven, A., Somerville, S. C., and Schulze-Lefert, P. 2003. SNARE-protein-mediated disease resistance at the plant cell wall. Nature 425:973-977.

Consonni, C., Humphry, M. E., Hartmann, H. A., Livaja, M., Durner, J., Westphal, L., Vogel, J. P., Lipka, V., Kemmerling, B., Schulze-Lefert, P., Somerville, S. C., and Panstruga, R. 2006. Conserved requirement for a plant host cell protein in powdery mildew pathogenesis. Nat. Genet. 38:716-720.

Consonni, C., Bednarek, P., Humphry, M. E., Francocci, F., Ferrari, S., Harzen, A., van Themaat, E. V. L., and Panstruga, R. 2010. Tryptophanderived metabolites are required for antifungal defense in the Arabidopsis mlo2 mutant. Plant Physiol. 152:1544-1561.

Czembor, J. H., Czembor, P. C., Doraczyńska, O., Pietrusińska, A., and Radecka-Janusik, M. 2016. Transfer of the mlo resistance gene into to the genome of winter barley. Prog Plant Prot 56:379-387.

Dean, R., van Kan, J. A. L., Pretorius, Z. A., Hammond-Kosack, K. E., Di Pietro, A., Spanu, P. D., Rudd, J. J., Dickman, M., Kahmann, R., Ellis, J., and Foster, G. D. 2012. The top 10 fungal pathogens in molecular plant pathology. Mol. Plant Pathol. 13:414-430.

Devoto, A., Piffanelli, P., Nilsson, I., Wallin, E., Panstruga, R., von Heijne, G., and Schulze-Lefert, P. 1999. Topology, subcellular localization, and sequence diversity of the Mlo family in plants. J. Biol. Chem. 274: 34993-35004

Devoto, A., Hartmann, H. A., Piffanelli, P., Elliott, C., Simmons, C., Taramino, G., Goh, C.-S., Cohen, F. E., Emerson, B. C., Schulze-Lefert, P., and Panstruga, R. 2003. Molecular phylogeny and evolution of the plant-specific seven-transmembrane MLO family. J. Mol. Evol. 56:77-88.

Eichmann, R., Bischof, M., Weis, C., Shaw, J., Lacomme, C., Schweizer, P., Duchkov, D., Hensel, G., Kumlehn, J., and Hückelhoven, R. 2010. BAX INHIBITOR-1 is required for full susceptibility of barley to powdery mildew. Mol. Plant-Microbe Interact 23:1217-1227.

Elliott, C., Zhou, F., Spielmeyer, W., Panstruga, R., and Schulze-Lefert, P. 2002. Functional conservation of wheat and rice Mlo orthologs in defense modulation to the powdery mildew fungus. Mol. Plant-Microbe Interact 15:1069-1077.

Elliott, C., Müller, J., Miklis, M., Bhat, R. A., Schulze-Lefert, P., and Panstruga, R. 2005. Conserved extracellular cysteine residues and cytoplasmic loop-loop interplay are required for functionality of the heptahelical MLO protein. Biochem. J. 385:243-254.

Feechan, A., Jermakow, A. M., Torregrosa, L., Panstruga, R., and Dry, I. B. 2008. Identification of grapevine $M L O$ gene candidates involved in susceptibility to powdery mildew. Funct. Plant Biol. 35:1255.

Feechan, A., Jermakow, A. M., Ivancevic, A., Godfrey, D., Pak, H., Panstruga, R., and Dry, I. B. 2013. Host cell entry of powdery mildew is correlated with endosomal transport of antagonistically acting VvPEN1 and VvMLO to the papilla. Mol. Plant-Microbe Interact 26:1138-1150.

Freialdenhoven, A., Scherag, B., Hollricher, K., Collinge, D. B., ThordalChristensen, H., and Schulze-Lefert, P. 1994. Nar-1 and Nar-2, two loci required for Mla12-specified race-specific resistance to powdery mildew in barley. Plant Cell 6:983-994.

Freialdenhoven, A., Peterhänsel, C., Kurth, J., Kreuzaler, F., and SchulzeLefert, P. 1996. Identification of genes required for the function of nonrace-specific mlo resistance to powdery mildew in barley. Plant Cell 8: $5-14$.

Freymark, G., Diehl, T., Miklis, M., Romeis, T., and Panstruga, R. 2007. Antagonistic control of powdery mildew host cell entry by barley calciumdependent protein kinases (CDPKs). Mol. Plant-Microbe Interact 20: 1213-1221.

Fujimura, T., Sato, S., Tajima, T., and Arai, M. 2016. Powdery mildew resistance in the Japanese domestic tobacco cultivar Kokubu is associated with aberrant splicing of $M L O$ orthologs. Plant Pathol. 65:1358-1365.

Ge, X., Deng, W., Lee, Z. Z., López-Ruiz, F. J., Schweizer, P., and Ellwood, S. R. 2016. Tempered mlo broad-spectrum resistance to barley powdery mildew in an Ethiopian landrace. Sci. Rep. 6:29558.

Glawe, D. A. 2008. The powdery mildews: A review of the world's most familiar (yet poorly known) plant pathogens. Annu. Rev. Phytopathol. 46:27-51.

Hentrich, W. 1979. Multiple Allelie, Pleiotropie und züchterische Nutzung mehltauresistenter Mutanten des mlo-Locus der Gerste. Tag.-Ber. Akad. Landwirtsch. Wiss. 175:191-202.

Hofer, K., Linkmeyer, A., Textor, K., Hückelhoven, R., and Hess, M. 2015. MILDEW LOCUS $O$ mutation does not affect resistance to grain infections with Fusarium spp. and Ramularia collo-cygni. Phytopathology 105:1214-1219.

Howlader, J., Kim, H.-T., Park, J.-I., Ahmed, N. U., Robin, A. H. K., Jung, H.-J., and Nou, I.-S. 2016. Expression profiling of $M L O$ family genes under Podosphaera xanthii infection and exogenous application of phytohormones in Cucumis melo L. J. Life Sci. 26:419-430.

Huang, S., Weigel, D., Beachy, R. N., and Li, J. 2016. A proposed regulatory framework for genome-edited crops. Nat. Genet. 48:109-111.

Hückelhoven, R., Trujillo, M., and Kogel, K.-H. 2000. Mutations in Rorl and Ror2 genes cause modification of hydrogen peroxide accumulation in $m l o$-barley under attack from the powdery mildew fungus. Mol. Plant Pathol. 1:287-292.

Hückelhoven, R., Dechert, C., and Kogel, K.-H. 2003. Overexpression of barley BAX inhibitor 1 induces breakdown of mlo-mediated penetration resistance to Blumeria graminis. Proc. Natl. Acad. Sci. U.S.A. 100:5555-5560.

Humphry, M. E., Bednarek, P., Kemmerling, B., Koh, S., Stein, M., Göbel, U., Stüber, K., Piślewska-Bednarek, M., Loraine, A., Schulze-Lefert, P., Somerville, S. C., and Panstruga, R. 2010. A regulon conserved in monocot and dicot plants defines a functional module in antifungal plant immunity. Proc. Natl. Acad. Sci. U.S.A. 107:21896-21901.

Humphry, M. E., Reinstädler, A., Ivanov, S., Bisseling, T., and Panstruga, R. 2011. Durable broad-spectrum powdery mildew resistance in pea erl plants is conferred by natural loss-of-function mutations in PSMLO1. Mol. Plant Pathol. 12:866-878.

Ihara-Ohori, Y., Nagano, M., Muto, S., Uchimiya, H., and Kawai-Yamada, M. 2007. Cell death suppressor Arabidopsis BAX inhibitor-1 is associated with calmodulin binding and ion homeostasis. Plant Physiol. 143:650-660. 
Iovieno, P., Andolfo, G., Schiavulli, A., Catalano, D., Ricciardi, L., Frusciante, L., Ercolano, M. R., and Pavan, S. 2015. Structure, evolution and functional inference on the Mildew Locus $O(M L O)$ gene family in three cultivated Cucurbitaceae spp. BMC Genomics 16:1112.

Jansen, C., von Wettstein, D., Schäfer, W., Kogel, K.-H., Felk, A., and Maier, F. J. 2005. Infection patterns in barley and wheat spikes inoculated with wild-type and trichodiene synthase gene disrupted Fusarium graminearum. Proc. Natl. Acad. Sci. U.S.A. 102:16892-16897.

Jarosch, B., Kogel, K.-H., and Schaffrath, U. 1999. The ambivalence of the barley Mlo locus: Mutations conferring resistance against powdery mildew (Blumeria graminis f. sp. hordei) enhance susceptibility to the rice blast fungus Magnaporthe grisea. Mol. Plant-Microbe Interact 12: 508-514.

Jarosch, B., Collins, N. C., Zellerhoff, N., and Schaffrath, U. 2005. RAR1, $R O R 1$, and the actin cytoskeleton contribute to basal resistance to Magnaporthe grisea in barley. Mol. Plant-Microbe Interact 18:397-404.

Jinek, M., Chylinski, K., Fonfara, I., Hauer, M., Doudna, J. A., and Charpentier, E. 2012. A programmable dual-RNA-guided DNA endonuclease in adaptive bacterial immunity. Science 337:816-821.

Jiwan, D., Roalson, E. H., Main, D., and Dhingra, A. 2013. Antisense expression of peach mildew resistance locus $\mathrm{O}$ ( PpMlol) gene confers cross-species resistance to powdery mildew in Fragaria $\times$ ananassa Transgenic Res. 22:1119-1131.

Jørgensen, J. H. 1992. Discovery, characterization and exploitation of Mlo powdery mildew resistance in barley. Euphytica 63:141-152.

Jørgensen, J. H., and Mortensen, K. 1977. Primary infection by Erysiphe graminis f. sp. horde $i$ of barley mutants with resistance genes in the $\mathrm{ml}$ - $\mathrm{O}$ locus. Phytopathology 67:678-685.

Jørgensen, J. H., and Wolfe, M. 1994. Genetics of powdery mildew resistance in barley. CRC Crit Rev Plant Sci 13:97-119.

Kaufmann, H., Qiu, X., Wehmeyer, J., and Debener, T. 2012. Isolation, molecular characterization, and mapping of four rose $M L O$ orthologs. Front. Plant Sci. 3:244.

Kim, D. S., and Hwang, B. K. 2012. The pepper MLO gene, CaMLO2, is involved in the susceptibility cell-death response and bacterial and oomycete proliferation. Plant J. 72:843-855.

Kim, M. C., Panstruga, R., Elliott, C., Müller, J., Devoto, A., Yoon, H. W. Park, H. C., Cho, M. J., and Schulze-Lefert, P. 2002. Calmodulin interacts with MLO protein to regulate defence against mildew in barley. Nature 416:447-451.

Kuhn, H., Kwaaitaal, M., Kusch, S., Acevedo-Garcia, J., Wu, H., and Panstruga, R. 2016. Biotrophy at its best: Novel findings and unsolved mysteries of the Arabidopsis-powdery mildew pathosystem. Arabidopsis Book 14:e0184.

Kumar, J., Hückelhoven, R., Beckhove, U., Nagarajan, S., and Kogel, K.-H 2001. A compromised Mlo pathway affects the response of barley to the necrotrophic fungus Bipolaris sorokiniana (Teleomorph: Cochliobolus sativus) and its toxins. Phytopathology91:127-133.

Kusch, S., Pesch, L., and Panstruga, R. 2016. Comprehensive phylogenetic analysis sheds light on the diversity and origin of the MLO family of integral membrane proteins. Genome Biol. Evol. 8:878-895

Le Fevre, R., O’Boyle, B., Moscou, M. J., and Schornack, S. 2016 Colonization of barley by the broad-host hemibiotrophic pathogen Phytophthora palmivora uncovers a leaf development-dependent involvement of Mlo. Mol. Plant-Microbe Interact 29:385-395.

Lyngkjær, M. F., and Carver, T. L. W. 2000. Conditioning of cellular defence responses to powdery mildew in cereal leaves by prior attack. Mol. Plant Pathol. 1:41-49.

Lyngkjær, M. F., and Østergård, H. 1998. Interaction between powdery mildew and barley with mlo5 mildew resistance. Plant Pathol. 47: 252-258.

Lyngkjær, M. F., Jensen, H. P., and Østergård, H. 1995. A Japanese powdery mildew isolate with exceptionally large infection efficiency on $\mathrm{mlo}$ resistant barley. Plant Pathol. 44:786-790.

Lyngkjær, M. F., Carver, T. L. W., and Zeyen, R. J. 1997. Suppression of resistance to Erysiphe graminis f.sp. hordei conferred by the mlo5 barley powdery mildew resistance gene. Physiol. Mol. Plant Pathol. 50:17-36.

Makepeace, J. C., Oxley, S. J. P., Havis, N. D., Hackett, R., Burke, J. I., and Brown, J. K. M. 2007. Associations between fungal and abiotic leaf spotting and the presence of mlo alleles in barley. Plant Pathol. 56: 934-942.

McGrann, G. R. D., Stavrinides, A., Russell, J., Corbitt, M. M., Booth, A., Chartrain, L., Thomas, W. T. B., and Brown, J. K. M. 2014. A trade off between mlo resistance to powdery mildew and increased susceptibility of barley to a newly important disease, Ramularia leaf spot. J. Exp. Bot. 65:1025-1037.

Miao, L. X., Jiang, M., Zhang, Y. C., Yang, X. F., Zhang, H. Q., Zhang, Z. F., Wang, Y. Z., and Jiang, G. H. 2016. Genomic identification, phylogeny, and expression analysis of $M L O$ genes involved in susceptibility to powdery mildew in Fragaria vesca. Genet. Mol. Res. 15:gmr.15038400.

Miklis, M., Consonni, C., Bhat, R. A., Lipka, V., Schulze-Lefert, P., and Panstruga, R. 2007. Barley MLO modulates actin-dependent and actinindependent antifungal defense pathways at the cell periphery. Plant Physiol. 144:1132-1143.

Newton, A. C., and Young, I. M. 1996. Temporary partial breakdown of Mlo-resistance in spring barley by the sudden relief of soil water stress. Plant Pathol. 45:973-977.

Nie, J., Wang, Y., He, H., Guo, C., Zhu, W., Pan, J., Li, D., Lian, H., Pan, J., and Cai, R. 2015. Loss-of-function mutations in CsMLO1 confer durable powdery mildew resistance in cucumber (Cucumis sativus L.). Front. Plant Sci. 6:1155.

O'Connell, R. J., and Panstruga, R. 2006. Tête à tête inside a plant cell Establishing compatibility between plants and biotrophic fungi and oomycetes. New Phytol. 171:699-718.

Opalski, K. S., Schultheiss, H., Kogel, K.-H., and Hückelhoven, R. 2005. The receptor-like MLO protein and the RAC/ROP family G-protein RACB modulate actin reorganization in barley attacked by the biotrophic powdery mildew fungus Blumeria graminis f. sp. hordei. Plant J. 41:291-303.

Panstruga, R. 2005. Serpentine plant MLO proteins as entry portals for powdery mildew fungi. Biochem. Soc. Trans. 33:389-392.

Pavan, S., Schiavulli, A., Appiano, M., Marcotrigiano, A. R., Cillo, F. Visser, R. G. F., Bai, Y., Lotti, C., and Ricciardi, L. 2011. Pea powdery mildew erl resistance is associated to loss-of-function mutations at a MLO homologous locus. Theor. Appl. Genet. 123:1425-1431.

Pessina, S., Pavan, S., Catalano, D., Gallotta, A., Visser, R. G. F., Bai, Y., Malnoy, M., and Schouten, H. J. 2014. Characterization of the MLO gene family in Rosaceae and gene expression analysis in Malus domestica. BMC Genomics 15:618.

Pessina, S., Angeli, D., Martens, S., Visser, R. G. F., Bai, Y., Salamini, F., Velasco, R., Schouten, H. J., and Malnoy, M. 2016a. The knock-down of the expression of $M d M L O 19$ reduces susceptibility to powdery mildew (Podosphaera leucotricha) in apple (Malus domestica). Plant Biotechnol. J. 14:2033-2044.

Pessina, S., Lenzi, L., Perazzolli, M., Campa, M., Dalla Costa, L., Urso, S., Valè, G., Salamini, F., Velasco, R., and Malnoy, M. 2016b. Knockdown of $M L O$ genes reduces susceptibility to powdery mildew in grapevine. Hortic Res 3:16016.

Peterhänsel, C., Freialdenhoven, A., Kurth, J., Kolsch, R., and SchulzeLefert, P. 1997. Interaction analyses of genes required for resistance responses to powdery mildew in barley reveal distinct pathways leading to leaf cell death. Plant Cell 9:1397-1409.

Piffanelli, P., Zhou, F., Casais, C., Orme, J., Jarosch, B., Schaffrath, U., Collins, N. C., Panstruga, R., and Schulze-Lefert, P. 2002. The barley MLO modulator of defense and cell death is responsive to biotic and abiotic stress stimuli. Plant Physiol. 129:1076-1085.

Piffanelli, P., Ramsay, L., Waugh, R., Benabdelmouna, A., D'Hont, A., Hollricher, K., Jørgensen, J. H., Schulze-Lefert, P., and Panstruga, R. 2004. A barley cultivation-associated polymorphism conveys resistance to powdery mildew. Nature 430:887-891.

Pinnschmidt, H. O., and Sindberg, S. A. 2009. Assessing Ramularia leaf spot resistance of spring barley cultivars in the presence of other diseases. Asp. Appl. Biol. 92:71-80

Qiu, X., Jian, H., Wang, Q., Tang, K., and Bao, M. 2015a. Expression pattern analysis of four Mlo genes from rose. J. Am. Soc. Hortic. Sci. 140:333-338.

Qiu, X., Wang, Q., Zhang, H., Jian, H., Zhou, N., Ji, C., Yan, H., Bao, M., and Tang, K. 2015b. Antisense RhMLO1 gene transformation enhances resistance to the powdery mildew pathogen in Rosa multiflora. Plant Mol. Biol. Report. 33:1659.

Reinstädler, A., Müller, J., Czembor, J. H., Piffanelli, P., and Panstruga, R. 2010. Novel induced mlo mutant alleles in combination with sitedirected mutagenesis reveal functionally important domains in the heptahelical barley Mlo protein. BMC Plant Biol. 10:31.

Rubiales, D., and Fondevilla, S. 2012. Future prospects for ascochyta blight resistance breeding in cool season food legumes. Front. Plant Sci. 3:27

Schouten, H. J., Krauskopf, J., Visser, R. G. F., and Bai, Y. 2014 Identification of candidate genes required for susceptibility to powdery or downy mildew in cucumber. Euphytica 200:475-486.

Schwarzbach, E. 1967. Recessive total resistance of barley to mildew (Erysiphe graminis D.C. f. sp. hordei Marchal) as a mutation induced by ethylmethansulfonate. Genetika a šlechtění 3:159-162.

Schwarzbach, E. 1979. Response to selection for virulence against the $m l-o$ based mildew resistance in barley, not fitting the gene-for-gene hypothesis Barley Genet. Newsl. 9:85-89.

Schwarzbach, E. 2001. Heat induced susceptibility of $m l o$-barley to powdery mildew (Blumeria graminis D.C. f.sp. hordei Marchal). Czech J. Genet Plant Breed. 37:82-87. 
Schwarzbach, E., Slater, S. E., and Clarkson, J. D. S. 2002. Occurrence of partially mlo-virulent isolates of barley powdery mildew in agricultural environments in Europe. Cereal Rusts and Powdery Mildews Bulletin. Published online.

Skou, J. P. 1982. Callose formation responsible for the powdery mildew resistance in barley with genes in the $m l-o$ locus. Phytopathol. Z. 104: 90-95.

Skou, J. P., Jørgensen, J. H., and Lilholt, U. 1984. Comparative studies on callose formation in powdery mildew compatible and incompatible barley. Phytopathol. Z. 109:147-168.

Stolzenburg, M. C., Aist, J. R., and Israel, H. W. 1984. The role of papillae in resistance to powdery mildew conditioned by the $m l$ - $o$ gene in barley. I. Correlative evidence. Physiol. Plant Pathol. 25:337-346.

Sun, S., Wang, Z., Fu, H., Duan, C., Wang, X., and Zhu, Z. 2015. Resistance to powdery mildew in the pea cultivar Xucai 1 is conferred by the gene erl. Crop J 3:489-499.

Sun, S., Deng, D., Wang, Z., Duan, C., Wu, X., Wang, X., Zong, X., and Zhu, Z. 2016a. A novel erl allele and the development and validation of its functional marker for breeding pea (Pisum sativum L.) resistance to powdery mildew. Theor. Appl. Genet. 129:909-919.

Sun, S., Fu, H., Wang, Z., Duan, C., Zong, X., and Zhu, Z. 2016b. Discovery of a novel erl allele conferring powdery mildew resistance in Chinese pea (Pisum sativum L.) landraces. PLoS One 11:e0147624.

Takamatsu, S. 2004. Phylogeny and evolution of the powdery mildew fungi (Erysiphales, Ascomycota) inferred from nuclear ribosomal DNA sequences. Mycoscience 45:147-157.

Takamatsu, S., Inagaki, M., Niinomi, S., Khodaparast, S. A., Shin, H.-D., Grigaliunaite, B., and Havrylenko, M. 2008. Comprehensive molecular phylogenetic analysis and evolution of the genus Phyllactinia (Ascomycota: Erysiphales) and its allied genera. Mycol. Res. 112:299315.

van Schie, C. C. N., and Takken, F. L. W. 2014. Susceptibility genes 101: How to be a good host. Annu. Rev. Phytopathol. 52:551-581.
Várallyay, É., Giczey, G., and Burgyán, J. 2012. Virus-induced gene silencing of Mlo genes induces powdery mildew resistance in Triticum aestivum. Arch. Virol. 157:1345-1350.

Vogel, J. P., and Somerville, S. C. 2000. Isolation and characterization of powdery mildew-resistant Arabidopsis mutants. Proc. Natl. Acad. Sci. U.S.A. 97:1897-1902.

von Röpenack, E., Parr, A., and Schulze-Lefert, P. 1998. Structural analyses and dynamics of soluble and cell wall-bound phenolics in a broad spectrum resistance to the powdery mildew fungus in barley. J. Biol. Chem. 273:9013-9022.

Walbot, V., Hoisington, D. A., and Neuffer, M. G. 1983. Disease lesion mimic mutations. Pages 431-442 in: Genetic Engineering of Plants. T. Kosuge, C. P. Meredith, A. Hollaender, and C. M. Wilson, eds. Springer US, Boston.

Wang, Y., Cheng, X., Shan, Q., Zhang, Y., Liu, J., Gao, C., and Qiu, J.-L. 2014 Simultaneous editing of three homoeoalleles in hexaploid bread wheat confers heritable resistance to powdery mildew. Nat. Biotechnol. 32:947-951.

Winterhagen, P., Howard, S. F., Qiu, W., and Kovács, L. G. 2008. Transcriptional up-regulation of grapevine $M L O$ genes in response to powdery mildew infection. Am. J. Enol. Vitic. 59:159-168.

Wolter, M., Hollricher, K., Salamini, F., and Schulze-Lefert, P. 1993. The mlo resistance alleles to powdery mildew infection in barley trigger a developmentally controlled defence mimic phenotype. Mol. Gen. Genet. 239:122-128.

Zheng, Z., Nonomura, T., Appiano, M., Pavan, S., Matsuda, Y., Toyoda, H., Wolters, A.-M. A., Visser, R. G. F., and Bai, Y. 2013. Loss of function in Mlo orthologs reduces susceptibility of pepper and tomato to powdery mildew disease caused by Leveillula taurica. PLoS One 8:e70723.

Zheng, Z., Appiano, M., Pavan, S., Bracuto, V., Ricciardi, L., Visser, R. G. F. Wolters, A.-M. A., and Bai, Y. 2016. Genome-wide study of the tomato SIMLO gene family and its functional characterization in response to the powdery mildew fungus Oidium neolycopersici. Front. Plant Sci. 7:380.

Zierold, U., Scholz, U., and Schweizer, P. 2005. Transcriptome analysis of mlomediated resistance in the epidermis of barley. Mol. Plant Pathol. 6:139-151. 